\title{
Eucoleus contortus (Nematoda: Capillariidae), a parasite of Cairina moschata domestica (Anseriformes: Anatidae) on Marajó Island, Pará State, in Brazilian Amazon
}

\author{
Eucoleus contortus (Nematoda: Capillariidae), um parasito de Cairina moschata domestica \\ (Anseriformes: Anatidae) na Ilha de Marajó, Estado do Pará, na Amazônia Brasileira \\ Elaine Lopes de Carvalho ${ }^{1,2}$ (1); Ricardo Luis Sousa Santana ${ }^{2}$ (1); Raul Henrique da Silva Pinheiro ${ }^{2,3}$ (D); \\ Elane Guerreiro Giese ${ }^{1,2 *}$ (1)
}

\begin{abstract}
${ }^{1}$ Programa de Pós-graduação em Saúde e Produção Animal na Amazônia, Instituto da Saúde e Produção Animal, Universidade Federal Rural da Amazônia - UFRA, Belém, PA, Brasil

${ }^{2}$ Laboratório de Histologia e Embriologia Animal, Instituto da Saúde e Produção Animal, Universidade Federal Rural da Amazônia UFRA, Belém, PA, Brasil

${ }^{3}$ Programa de Pós-graduaçáo em Sociedade, Natureza e Desenvolvimento, Instituto de Ciências e Tecnologia das Águas, Universidade Federal do Oeste do Pará - UFOPA, Santarém, PA, Brasil
\end{abstract}

Received July 27, 2019

Accepted October 21, 2019

\begin{abstract}
The family Capillariidae is one of the most important in the superfamily Trichinelloidea, with 27 genera and more than 300 species parasitizing vertebrates. This study considers the morphology, morphometry and prevalence of Eucoleus contortus parasitizing the Muscovy duck Cairina moschata domestica esophagus from Marajó Island, in State of Pará, Brazil. Morphologically the nematodes had a filiform body, with transversely striated cuticle, long esophagus, divided into two parts, one muscular and another consisting of stichocytes, spicule weakly sclerotized, spiny sheath and pseudobursa present in males. Females had a pre-equatorial vulva, barrel-shaped eggs and were bioperculated. In the northern region of Brazil, the Muscovy duck is an abundant bird, and one of the items in the food supply for human communities. The occurrence of E. contortus adds data to the biodiversity of parasites described in Anseriform birds of the Brazilian Amazon, especially those used as source of protein by human communities of Marajó.
\end{abstract}

Keywords: Nematoids, parasites, poultry, Amazon.

\section{Resumo}

A família Capillariidae é uma das mais importantes da superfamília Trichinelloidea, com 27 gêneros e mais de 300 espécies parasitando os vertebrados. Este estudo considera a morfologia, morfometria e prevalência de Eucoleus contortus parasito do esôfago de pato doméstico na Ilha de Marajó, Estado do Pará, Brasil. Morfologicamente os nematódeos apresentaram corpo filiforme, com cutícula estriada transversalmente, esôfago longo, dividido em duas partes, sendo uma muscular e outra formado por esticócitos, espículo fracamente esclerotizado, bainha espinhosa e pseudobursa presente nos machos. Fêmeas com vulva pré-equatorial, ovos em forma de barril e bioperculado. Na regiáo norte do Brasil, o pato doméstico é uma ave abundante, compondo um dos itens do suprimento de alimentos para muitas pessoas. A ocorrência de E. contortus adiciona dados à biodiversidade de parasitos descritos em aves Anseriformes da Amazônia brasileira, em especial as utilizadas como fonte de proteína por comunidades humanas do Marajó.

Palavras-chave: Nematoides, parasitos, aves domésticas, Amazônia.

\section{Introduction}

The family Capillariidae Neveu-Lemaire, 1936 is one of the most important in the superfamily Trichinelloidea Ward, 1907 (1879), with more than 300 known species parasitizing

*Corresponding author: Elane Guerreiro Giese. Laboratório de Histologia e Embriologia Animal, Instituto da Saúde e Produção Animal, Universidade Federal Rural da Amazônia - UFRA, Avenida Presidente Tancredo Neves, 2501, Terra Firme, CEP 66077-830, Belém, PA, Brasil. e-mail: elane.giese@ufra.edu.br. all vertebrate classes around the world (ANDERSON, 2000; GIBSON et al., 2014). The classification of capillariids is one of the most complex and unsatisfactory among nematodes, due to the scarcity of good morphological characteristics (SPRATT, 2006). Moreover, there are still problems with the correct identification of these parasites, and at present the classification system is based mainly on the morphology of males (MORAVEC \& JUSTINE, 
2010). This fact often results in descriptions of species lacking elucidative morphological data (FREITAS \& ALMEIDA, 1935; MORAVEC, 1982; STAPF et al., 2013).

In the Baylis (1928) conception, the morphological classification of capillariid members included all of them in the genus Capillaria sensus Zeder, 1800, and is not currently accepted by most helminthologists, but remains in use in the medical literature (MORAVEC, 2001). Because of this classification today, the genus Capillaria has a large number of synonymies resulting from different attempts to reorganize the genus taxonomically (BUTTERWORTH \& BEVERLEY-BURTON, 1980).

Cairina moschata domestica Linnaeus, 1758 (Muscovy ducks) is an important source of food for several human populations, since they provide meat and eggs (MATTOS et al., 2008). In the northern region of Brazil, the Muscovy duck is an abundant bird, composing one of the items in the food supply for human communities. As part of an ongoing study of the helminths of birds on Marajó Island, Brazil, samples of ducks were collected and necropsied. The objective of this study is to characterize the morphology, morphometry and prevalence of nematode Capillariidae parasites in Muscovy duck collected on Marajó Island, Brazilian Amazon.

\section{Materials and Methods}

The study used Nematoda Capillariidae obtained from 19 males and 11 females of $C$. moschata domestica aged 4-8 months and acquired from rural properties of the municipality of Soure $\left(00^{\circ} 43^{\prime} 00^{\prime \prime} \mathrm{S}\right.$; $\left.48^{\circ} 31^{\prime} 24^{\prime \prime} \mathrm{W}\right)$, in Marajó Island, Brazil. The Muscovy ducks were components of small extensively reared herds with free access to the environment, for the purpose of providing meat and eggs for families or for sale at local markets. These birds were slaughtered stunning with a club, cutting the blood vessels of the neck, exsanguination on the farm and only the organs of the digestive tract were transported to the Laboratório de Histologia e Embriologia Animal, Universidade Federal Rural da Amazônia, Campus Belém (Brazil). In the laboratory, the organs were separated and placed in Petri dishes with saline solution $\mathrm{NaCl} 0.9 \%$ and examined using a stereomicroscope. The recovered nematodes were fixed in a solution of AFA (93 parts 70\% ethyl alcohol, 5 parts formaldehyde, and 2 parts glacial acetic acid) and processed using light microscopy and scanning electron microscopy according to method described by Pinheiro et al. (2018). A total of 10 male specimens, 10 female specimens and 50 eggs were used for the morphometric analysis of the nematodes. Measurements are given in micrometers unless otherwise noted and are presented as the range (minimum and maximum values) followed by the mean in parentheses. Taxonomic classification of nematodes was in accordance with Vicente et al. (1995) and Gibbons (2010).

\section{Results}

\section{Survey data}

A total of 242 E. contortus were recovered from the Muscovy duck in the epithelium of the esophageal mucosa, and this species is not present in other organs. Host-parasite data showing prevalence $76.6 \%$ (23 infected hosts out of 30 analyzed), mean intensity of 10.52 , mean abundance of 8.15 and range of infection of 1 to 52 nematodes per bird. All specimens collected showed characteristics compatible with E. contortus (syn Capillaria contorta) (Nematoda: Capillariidae). The morphological and morphometric characteristics of the E. contortus are presented below:

Nematoda Rudolphi, 1808

Family Capillariidae Neveu-Lemaire, 1936

Eucoleus contortus (syn. Capillaria contorta) Creplin, 1839 (Gagarin, 1951)

(Based on light microscopy and scanning electron microscopy examination: Figures 1-3)

Medium-sized nematodes in relation to their congeners, filiform, with finely transversely striated cuticle. Cephalic region in button
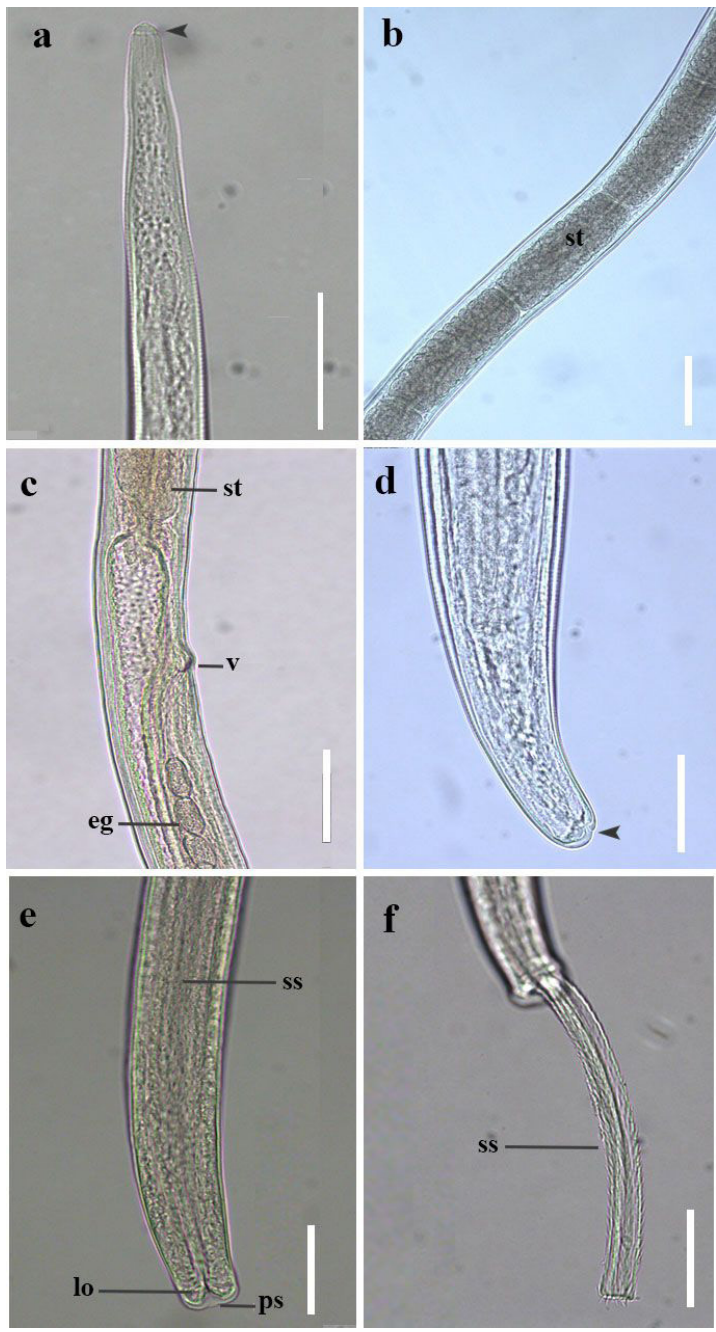

Figure 1. Scanning electron microscopy of eggs of Eucoleus contortus parasitizing the esophagus of Cairina moschata domestica in Pará State, Brazil. (a) Anterior end in button shape (arrowhead). Bar $=50 \mu \mathrm{m}$; (b) well defined stichocytes (st) with large and fragmented nuclei. Bar $=100 \mu \mathrm{m}$; (c) Esophageal-intestinal junction of the female, lateral view. End of stichocytes (st), vulva (v) and eggs (eg). Bar = $100 \mu \mathrm{m}$; (d) Female posterior extremity, lateral view, subterminal anal opening (arrowhead). Bar $=50 \mu \mathrm{m}$; (e) Tail of the male, ventral view, with retracted spiny spinal sheath (ss), caudal lobes (lo) and pseudobursa (ps). Bar $=50 \mu \mathrm{m}$; (f) Posterior end of a male, ventrolateral view, sheath extruded from cloaca (ss). Bar $=50 \mu \mathrm{m}$. 
format (Figures 1a, 2a). Oral aperture circular. Muscular esophagus short, narrow. Nerve ring circulating the muscular esophagus in its initial portion. Stichosome consisting of single row of about 33 elongate stichocytes with distinct transverse annulae (mean of the three initial, middle and final stichocytes); nuclei of stichocytes large and fragmented (Figure 1b). Two wing-like pseudocoelomatic glandular cells present at esophagus-intestinal junction. Two bacillary lateral bands along the body, more numerous in females.

Males (Based on 9 specimens with hem retracted and 1 specimen with sheath exposed): Body length of $14 \mathrm{~mm}$ (11-16); and maximum width at the junction between the esophagus and bowel of 48 (37-60). Length of muscular esophagus $276(223-307) \times 15(12-20)$, of stichosome $4 \mathrm{~mm}$ (3-5), number of stichocytes about 31 (25-44), stichocytes with distinct 13 (8-17) transverse annulae; nuclei of stichocytes large. Length of entire esophagus $5 \mathrm{~mm}$ (4-6), representing 34\% of body length. Nerve ring situated 69 (52-83) from anterior extremity. Spicule single, weakly sclerotized, measuring $770(600-980) \times 13(10-21)$; proximal end of spicule blunt. Spicular sheath spinous; length of part of sheath extruded from cloaca 177 , width 14 in only one specimen. Posterior end of body rounded, with two distinct, round dorsolateral lobes10 (10) long, and one pair papillae in each one lobes. Cloacal opening terminal, length of tail 13. Membrane pseudobursa present $13(10-15) \times 24$ (23-27) (Figures 1e, 2e).

Females (Based on 10 gravid specimens): Body length of $26 \mathrm{~mm}$ (21-29); and maximum width at the junction between the
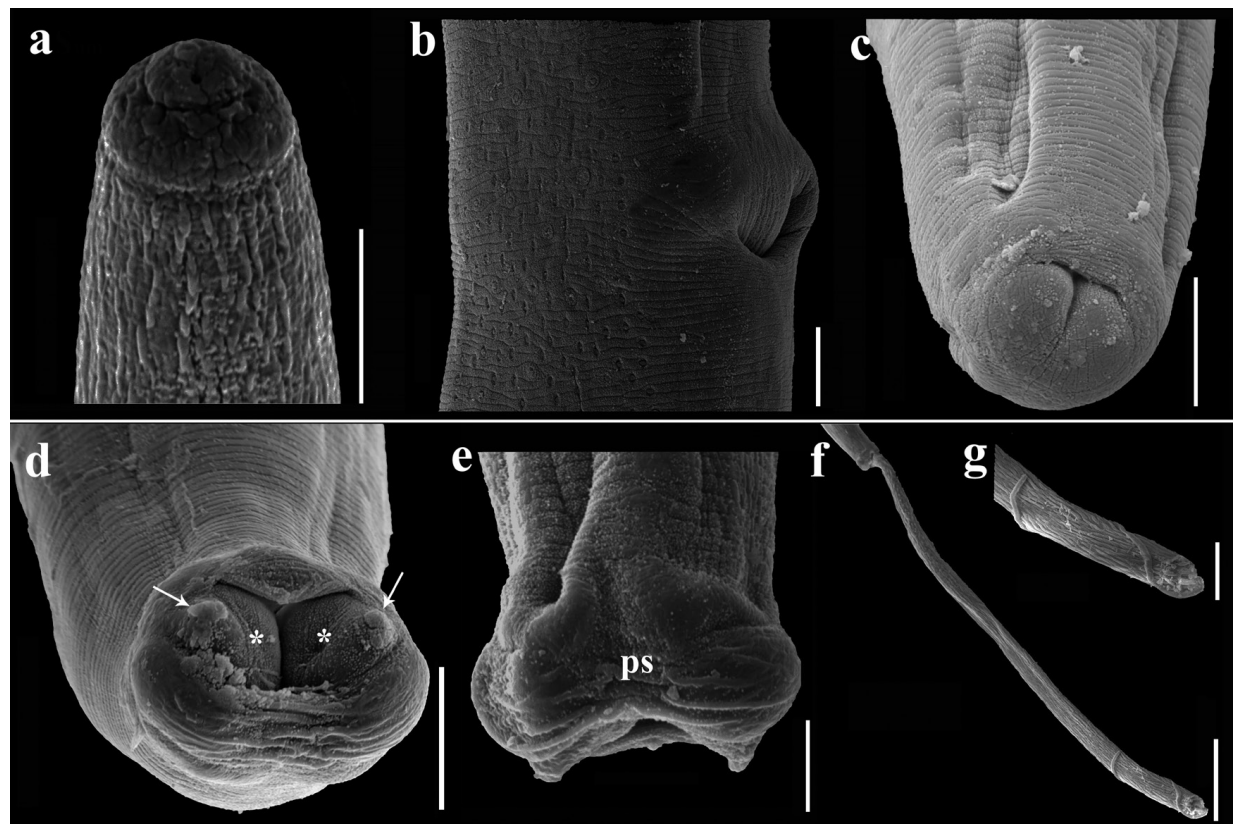

Figure 2. Scanning electron microscopy of E. contortus, parasitizing the esophagus of C. moschata domestica in Pará State, Brazil. (a) Anterior end in button shape (arrowhead). Bar $=5 \mu \mathrm{m}$; (b) Lateral view of the vulvar, showing lateral bacillary bands. Bar $=10 \mu \mathrm{m}$; (c) The posterior end of a female, with an anal opening. Bar $=10 \mu \mathrm{m}$; (d) Tail of the male in ventrolateral view, with caudal lobes $\left({ }^{*}\right)$, each with papilla (arrow); (e) Tail detail of the male, evidencing membranous pseudobursa (ps). Bar $=10 \mu \mathrm{m}$; (f) Tail lateral view of male with spiny sheath extruded. Bar $=50 \mu \mathrm{m}$; (g) Detail of the spinal sheath with the spines. Bar $=20 \mu \mathrm{m}$
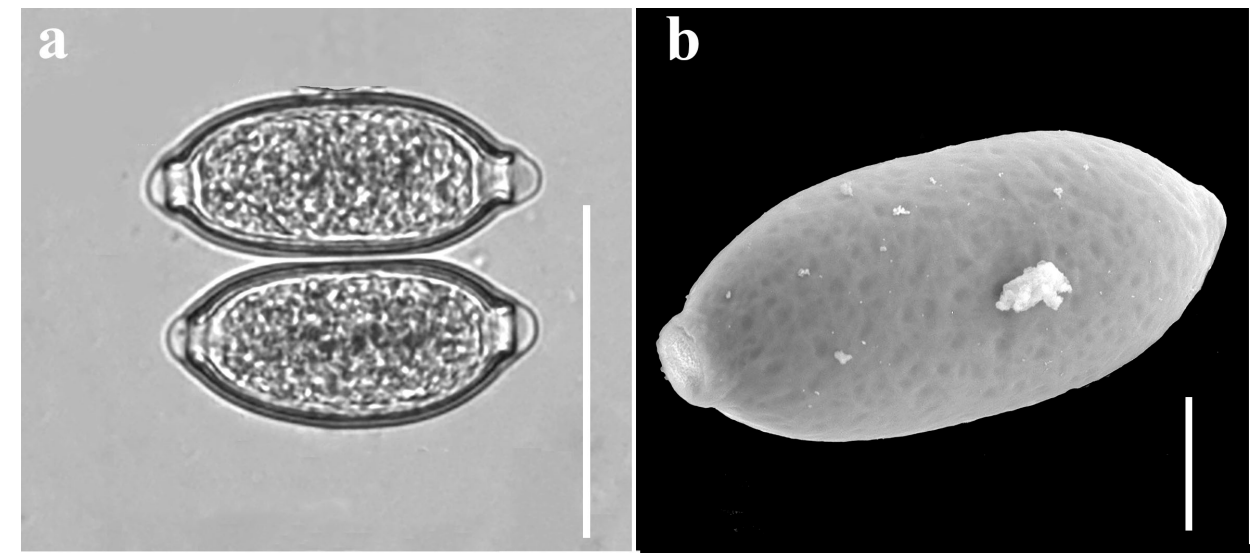

Figure 3. Photomicrographs and scanning electron microscopy of eggs of E. contortus parasitizing the esophagus of $C$. moschata domestica in Pará State, Brazil. (a-b) barrel-shaped eggs, with two well-defined asymmetric polar plugs, rough and porous shell surface. Bar a $=50 \mu \mathrm{m}$ and $\mathrm{Bar} b=10 \mu \mathrm{m}$. 
esophagus and bowel of 67 (43-77). Length of muscular esophagus $379(287-445) \times 15(7-23)$, of stichosome $6 \mathrm{~mm}$ (5-8), number of stichocytes about 32 (27-39), stichocytes with distinct 14 (8-16) number of transverse annulae; nuclei of stichocytes large. Length of entire esophagus $7 \mathrm{~mm}$ (5-8), representing 26\% of body length. Nerve ring situated 69 (50-87) from anterior extremity. Vulva located $7 \mathrm{~mm}$ (6-8) from anterior end of body, at $27 \%$ of body length. The distance from the end of the stichocytes to the vulva 165 (57-330). The upper lip of the vulva is more elevated than the lower lip. Vulvar appendix absent. Eggs arranged in single file in uterus. Eggs barrel shaped $50(40-90) \times 20$ (20-40), with protruding polar plugs $6(3-7) \times 9(5-9)$ (Fig. 3ab). Egg wall with layer hyaline, outer layer with fine superficial net-like sculpture. Caudal end rounded 8 (7-10), anus subterminal (Fig. 1I).

Taxonomy summary:

Eucoleus contortus (syn Capillaria contorta) Creplin, 1839 (Gagarin, 1951)

Host: Cairina moschata domestica Linnaeus, 1758 (Anseriformes: Anatidae);

Common name in Brasil: Pato do mato, pato bravo, pato selvagem, asa branca, pato bravo verdadeiro.

Site of infection: Epithelium of the esophageal mucosa.

Biome: Amazon and Environment: Estuarine

Location: Municipality of Soure (Latitud -0.541205; Longitud -48.670139), Microrregião do Arari, Pará, Brazil.

\section{Discussion}

The nematodes found inserted in the mucosa of the esophagus of Muscovy ducks raised extensively in the municipality of Soure, Marajó Island, State of Pará (Brazil), have characteristics similar to those of the Capillariidae family. Gibbons (2010) groups this family into 27 genus, of which 10 parasitize birds: Aonchotheca López-Neyra 1947; Baruscapillaria Moravec 1982; Brevitominx Travassos, Freitas \& Mendonça, 1964; Capillaria Zeder 1800; Echinocoleus López-Neyra 1947; Eucoleus Dujardin 1845; Ornithocapillaria Baruš \& Sergeeva 1990; Pseudocapillaria Freitas, Mendonça \& Guimarães, 1959; Pterothominx Freitas, Mendonça \& Guimarães, 1959; and Tridentocapillaria Barus \& Sergeeva 1990, with Capillaria, Eucoleus and Pseudocapillaria recorded as parasitizing ducks (MORAVEC, 1982; MORAVEC et al., 1987; STAPF et al., 2013).

The genus Eucoleus is composed of species that parasitize the respiratory tract, mucosa of the esophagus, buccal cavity and stomach of birds and mammals (MORAVEC, 1982; VICENTE et al., 1995; GIBBONS, 2010). Although Anderson (2000) and Anderson et al. (2009), employ Eucoleus as a synonym of Capillaria, Moravec (1982), Vicente et al. (1995) and Gibbons (2010) accept Eucoleus as a valid genus, with morphologically presenting males with thin spicule, moderately sclerotized with a long spinal sheath covered with cuticular spines, caudal lateral alae absent, two small lobes rounded laterally towards the posterior supporting a pseudobursa, and females with vulvae without an appendix.

The nematodes of the present study presented morphological and morphometric characteristics compatible with E. contortus. Creplin (1839) proposed E. contortus as a parasite of the oral cavity and esophagus of different birds (Anseriformes, Charadriiformes, Galliformes Falconiformes and Passeriformes) in Germany, but later, different authors re-described or added a new geographic distribution for the species, including Diesing (1851) in Falconiformes, Passeriformes and Charadriiformes from Austria; Eberth (1863) in Passeriformes from Germany; Linstow (1877) in Passeriformes, Charadriiformes and Anseriformes from Berlin; Railliet \& Lucet (1889) in Anseriformes from Paris; Cram (1936) in Galliformes, Charadriiformes and Anseriformes from United States; Chabaud (1952) in Charadriiformes from Paris and Mettrick (1959) in Galliformes and Anseriformes from England.

Muscovy ducks are extensively reared in most part of Brazil, and on the Marajó Island they are of great importance to the human populations as a source of food, although there are few data on their parasitic fauna. In Brazil, the first record of bird parasitic nematodes was made by Travassos (1915) in Anseriformes, Charadriiformes, Passeriformes, and Falconiformes, followed by Freitas \& Almeida (1935) in Passeriformes, Anseriformes, Charadriiformes, Falconiformes, and Galliformes; Freitas et al. (1959) in Galliformes, Piciformes and Psittaciformes, Mattos et al. (2008) in Anseriformes and Stapf et al. (2013) in Anseriformes. Although Brazil is one of the main refuges for resident and visiting birds, in discussions of work related to the parasites of these animals, only Vicente et al. (1995) has reviewed nematodes in birds in Brazil.

The use of scanning electron microscopy, although very common for nematodes, has rarely been applied for members of the Capillariidae family (MORAVEC \& BARTON, 2018), especially because of the difficulty in processing the samples. In this study using SEM, we observed details of the cephalic region in button shape, in female vulva with unraised lip, in males tail with pseudobursa, supported by two lobes, each lobe having a papilla, spinal sheath armed with spines, besides the difference in quantity of bacillary bands between males and females. Morphometric comparisons between Eucoleus contortus and its other re-descriptions, in addition to the comparison with other species found in Brazil, are presented in Table 1.

Eggs of E. contortus morphologically have a barrel shape, with polar plugs and a rough surface; morphometrically the eggs presented similarity in size with that already described in the literature for the species (see Table 1). Campbell \& Little (1991) states in his study that eggs of E. boehmi are characterized by having a barrel shape and polar plugs with small morphological differences. Macchioni et al. (2013), when analyzing dog feces in Italy with a prevalence of $7.4 \%$ of capillary parasites (E. aerophilus and E. boehmi) affirm that the use of molecular biology should be fundamental for the specific identification of family Capillariidae.

In this study, $76.6 \%$ of the analyzed ducks were parasitized by $E$. contortus in the esophageal mucosa. Different authors report parasitism and a high prevalence of $E$. contortus parasitizing the esophagus in different birds: Betlejewska et al. (2002) reported by $52.3 \%$ of parasitism in Anas platyrhynchos in the Northwest of Poland. Mattos et al. (2008) described the occurrence of E. carinae with prevalence of $6.6 \%$ in Muscovy ducks raised extensively in the State of Rio de Janeiro. Stapf et al. (2013) reported 24\% of prevalence in A. platyrhynchos and $40 \%$ of prevalence in 


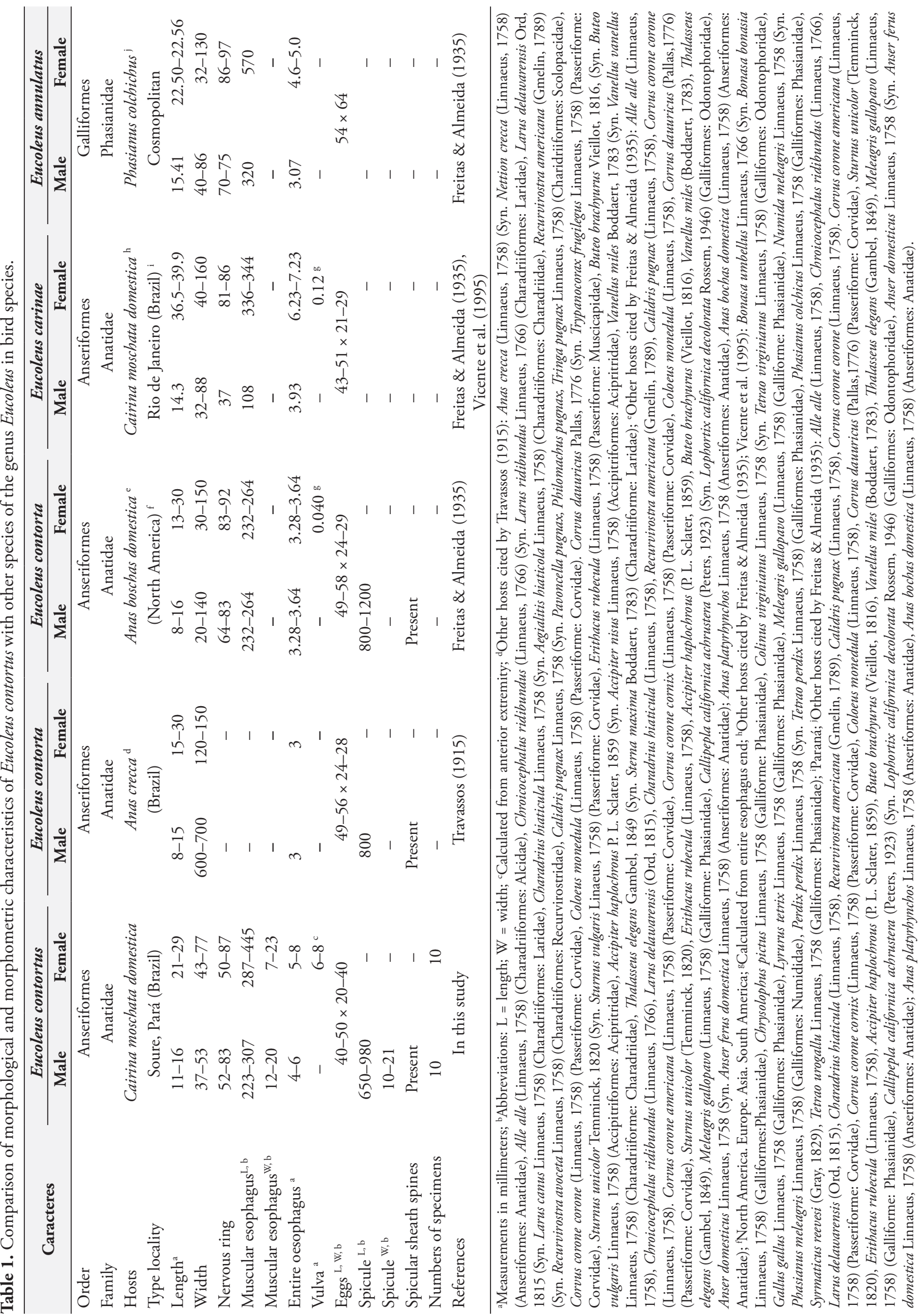




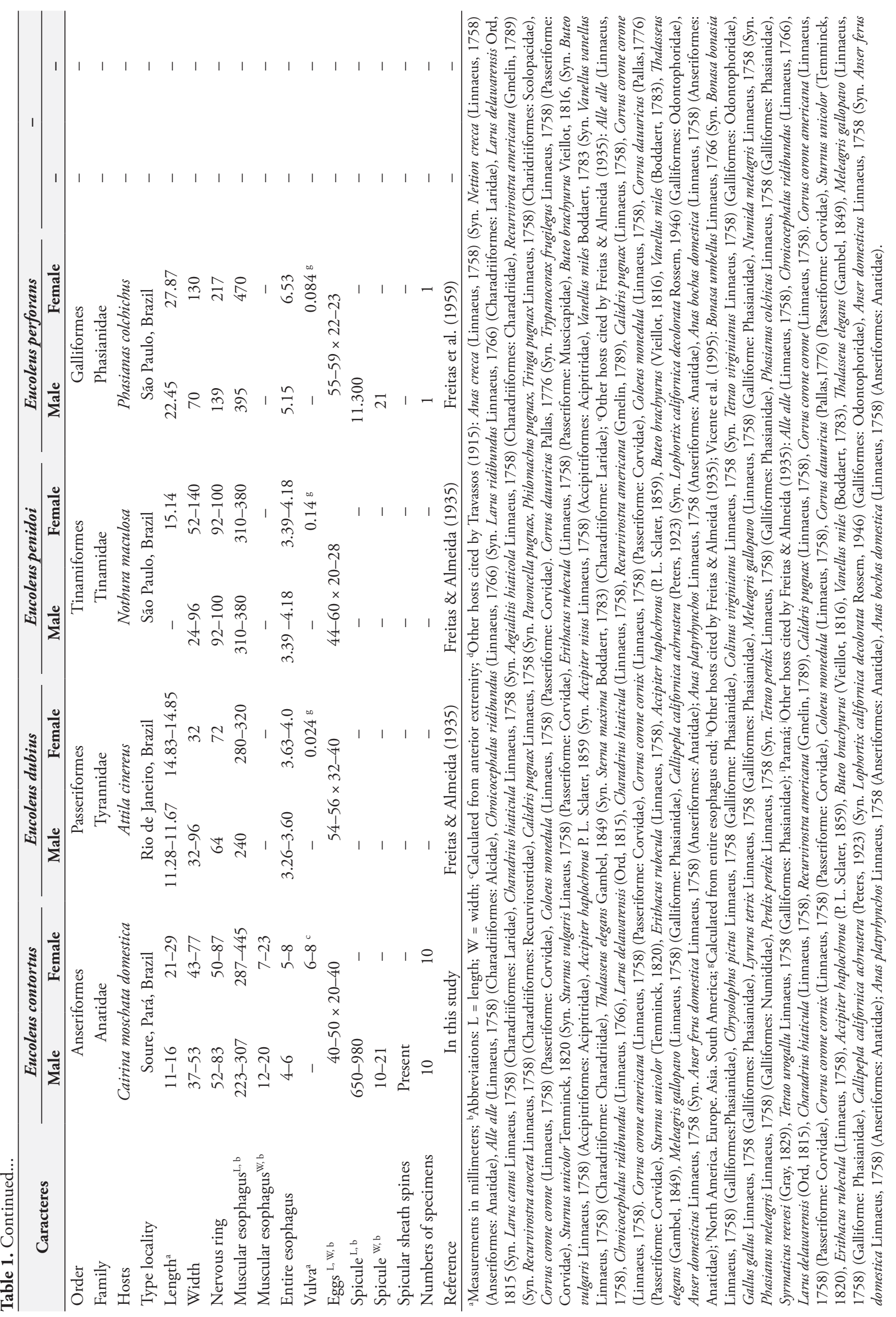


Anas clypeata in Northwest Poland, and Oliveira et al. (2017) found $16 \%$ of prevalence in Callipepla californica of Brazil.

In the Marajó Island, the local human population commonly uses Muscovy ducks for food and commerce. Most of these birds live in an open environment, using this space as shelter and to obtain food, besides being raised together with other birds, and domestic and wild animals. Endoparasite infections are almost inevitable in an extensive system due to the prolonged survival of eggs in the environment, especially when there is high humidity, which allows the greater survival of immature forms of helminths and increases the number of infectious stages in the soil, when capillary eggs can survive up to 11 months viable in the environment (YADAV \& TANDON, 1991; PERMIN et al., 2002; CARDOZO \& YAMAMURA, 2004; SOBRAL et al., 2010). Ruff (1999) and Vita et al. (2014) observed that for birds that are raised free, having access to other birds and domestic or wild animals in places with poor hygiene, in addition to direct contact with the ground, this is the ideal environment for the proliferation of parasitic diseases.

The high prevalence of nematodes in Muscovy duck from the Marajó Island may be related to the interaction of these birds with the soil, which is essential for the maintenance of the life cycle of many parasites, such as E. contortus, where the birds ingest the intermediate host, possibly earthworms, besides the viable eggs in the environment (CARDOZO \& YAMAMURA, 2004).

\section{Conclusions}

The Muscovy duck is an important source of animal protein for the human population of Marajó and the knowledge of its nematofauna is important information to understand the pathogens that can affect poultry and that reduce poultry production in the country, so that measures can be taken for the purpose of avoiding possible zoonoses.

\section{Acknowledgements}

The authors are grateful to the following the Laboratório de Histologia e Embriologia Animal and Laboratório de Microscopia Eletrônica de Varredura - Instituto da Saúde e Produção Animal - Universidade Federal Rural da Amazônia - UFRA, campus Belém, state of Pará, Brazil for the use of the scanning electron microscope. This study is part of the master dissertation of the first author from the Programa de Saúde e Produção Animal da Amazônia, Universidade Federal Rural da Amazônia. This study was financed in part by the Coordenação de Aperfeiçoamento de Pessoal de Nível Superior - Brasil (CAPES) - Finance Code 001”, Ministério da Educação do Brasil. Raul Henrique da Silva Pinheiro was supported by a research fellowship from the "Universidade Federal do Oeste do Pará - CAPES-BRASIL”.

\section{References}

Anderson RC, Chabaud AG, Willmott S. Keys to the nematode parasites of vertebrates. Wallingford: CABI International; 2009. http://dx.doi.org /10.1079/9781845935726.0000.
Anderson RC. Nematode parasites of vertebrates. Their development and transmission. 2nd ed. CABI Publishing. 2000. http://dx.doi.org/10.107 9/9780851994215.0000.

Baylis HA. XLI - Records of some parasitic worms from British vertebrates. Ann Mag Nat Hist 1928; 1(3): 329-343. http://dx.doi. org/10.1080/00222932808672790.

Betlejewska K, Kalisińska E, Kornyushin V, Salamatin R. Eucoleus contortus (Creplin, 1839) nematode in mallard (Anas platyrhynchos Linnaeus, 1758) from north-western Poland. Electron J Pol Agric Univ 2002; 5(1): 3.

Butterworth EW, Beverley-Burton M. The taxonomy of Capillaria spp. (Nematoda: Trichuroidea) in carnivorous mammals from Ontario, Canada. Syst Parasitol 1980; 1(3-4): 211-236. http://dx.doi.org/10.1007/ BF00009847.

Campbell BG, Little MD. Identification of the eggs of a nematode (Eucoleus boehmi) from the nasal mucosa of North American dogs. J Am Vet Med Assoc 1991; 198(9): 1520-1523. PMid:2061172.

Cardozo SP, Yamamura MH. Parasites in free-range chickens system in Brazil. Semina: Ciênc Agrár 2004; 25(1): 63-74.

Chabaud AG. Sur un Capillaria du vanneau. Ann Parasitol Hum Comp 1952; 27(4): 400-406. http://dx.doi.org/10.1051/parasite/1952274400. PMid:14953032.

Cram EB. Species of Capillaria parasitic in the upper digestive tract of birds. Washington: United States Department of Agriculture; 1936

Creplin FCH. Eingeweiderwürmer, Binnenwürmer, Thierwürmer. In: Ersch JS, Gruber JG. Allgemeine Encyklopädie der Wissenschaften und der Künste. Leipzig; 1839. p. 277-302.

Diesing KM. Systema helminthum. Vindobonae: Sumptibus Academiae Caesareae Scientiarum; 1851.

Eberth KJ. Untersuchungen über Nematoden. W. Engelmann, 1863.

Freitas JFT, Almeida JL. Sobre os nematoda Capillariinae parasitas de esophago e papo de aves. Mem Inst Oswaldo Cruz 1935; 30(2): 123-156. http://dx.doi.org/10.1590/S0074-02761935000800001.

Freitas JFT, Mendonça JM, Guimarães JP. Sôbre algumas espécies do gênero Capillaria Zeder, 1800 parasitas de aves: (Nematoda, Trichuroidea). Mem Inst Oswaldo Cruz 1959; 57(1): 17-31. http://dx.doi.org/10.1590/ S0074-02761959000100002. PMid:13814750.

Gibbons LM. Keys to the nematode parasites of vertebrates: supplementary volume. Oxon: Cabi Publishing; 2010.

Gibson DI, Bray RA, Hunt D, Georgiev BB, Scholz T, Harris PD, et al. Fauna Europaea: Helminths (animal parasitic). Biodivers Data J 2014 2(2): e1060. http://dx.doi.org/10.3897/BDJ.2.e1060. PMid:25349520.

Linstow OFB. Enthelminthologica. Arch Naturgesch 1877; 43(1): 173-198.

Macchioni F, Guardone L, Prati MC, Magi M. Eucoleus aerophilus (syn. Capillaria aerophila) and other Trichinelloid nematodes in dogs from Liguria (Northwest Italy). In: Boiti C, Ferlazzo A, Gaiti A, Pugliese A. Trends in veterinary sciences. Berlin: Springer; 2013. p. 85-89. http:// dx.doi.org/10.1007/978-3-642-36488-4_16.

Mattos DG Jr, Costa DA, Menezes RC, Mesquita EM. Prevalence of helmintos in domestic ducks Cairina moschata dom. (Linné) (Anseriformes, Anatidae, Cairinini, Cairina) proceeding from extensive creations in the state of Rio de Janeiro, Brazil. R Bras Ci Vet 2008; 15(3): 140-142.

Mettrick DF. On the nematode genus Capillaria in British birds. Ann Mag Nat Hist 1959; 2(14): 65-84. http://dx.doi.org/10.1080/00222935908651029. 
Moravec F, Barton DP. Capillaria appendigera n. sp. (Nematoda: Capillariidae) from the goldbanded jobfish Pristipomoides multidens (Day) (Lutjanidae) and new records of other intestinal capillariids from marine perciform fishes off Australia. Syst Parasitol 2018; 95(1): 55-64. http:// dx.doi.org/10.1007/s11230-017-9764-y. PMid:29168151.

Moravec F, Justine JL. Some trichinelloid nematodes from marine fishes off New Caledonia, including description of Pseudocapillaria novaecaledoniensis sp. nov. (Capillariidae). Acta Parasitol 2010; 55(1): 71-80. http://dx.doi. org/10.2478/s11686-010-0005-7.

Moravec F, Prokopic J, Shlikas AV. The biology of nematodes of the family Capillariidae Neveu-Lemaire, 1936. Folia Parasitol (Praha) 1987; 34(1): 39-56. PMid:3583129.

Moravec F. Proposal of a new systematic arrangement of nematodes of the family Capillariidae. Folia Parasitol (Praha) 1982; 29(2): 119-132. PMid:7106653.

Moravec F. Redescription and systematic status of Capillaria philippinensis, an intestinal parasite of human beings. J Parasitol 2001; 87(1): 161-164. http://dx.doi.org/10.1645/0022-3395(2001)087[0161:RASSOC]2.0. CO;2. PMid:11227884

Oliveira LGSD, Lipinski GP, Lorenzett MP, Rolim VM, Marques SMT, Driemeier D, et al. Causes of bird losses recorded in a captive-bred wild bird flock between 2011 and 2015. Cienc Rural 2017; 47(5): e20160903. http://dx.doi.org/10.1590/0103-8478cr20160903.

Permin A, Esmann JB, Hoj CH, Hove T, Mukaratirwa S. Ecto, endo and haemoparasites in free-range chickens in the Goromonzi District in Zimbabwe. Prev Vet Med 2002; 54(3): 213-224. http://dx.doi.org/10.1016/ S0167-5877(02)00024-7. PMid:12114010.

Pinheiro RHS, Melo FTV, Monks S, Santos JN, Giese EG. A new species of Procamallanus Baylis, 1923 (Nematoda, Camallanidae) from Astronotus ocellatus (Agassiz, 1831) (Perciformes, Cichlidae) in Brazil. ZooKeys
2018; 790(790): 21-33. http://dx.doi.org/10.3897/zookeys.790.24745. PMid:30364795.

Railliet A, Lucet A. Sur la presence eu Trichosoma Contortum Creplin chez le canard domestique. Bull Soc Zool Fr 1889; 14: 382-383.

Ruff MD. Important parasites in poultry production systems. Vet Parasitol 1999; 84(3-4): 337-347. http://dx.doi.org/10.1016/S03044017(99)00076-X. PMid:10456422.

Sobral FES, Brandão PA, Athayde ACR. Utilização de fitoterápicos no tratamento de parasitoses em galinhas caipira criadas em sistema semiextensivo. Agropec Cient Semi-Árido 2010; 6(1): 1-6.

Spratt DM. Description of capillariid nematodes (Trichinelloidea: Capillariidae) parasitic in Australian marsupials and rodents. Zootaxa 2006; 1348(1): 1-82. http://dx.doi.org/10.11646/zootaxa.1348.1.1.

Stapf AN, Kavetska KM, Ptak PP, Rząd I. Morphometrical and ecological analysis of nematodes of the family Capillariidae (Neveu-Lemaire, 1936) in wild ducks (Anatinae) from the north-western Poland. Ann Parasitol 2013; 59(4): 195-201. PMid:24791347.

Travassos L. Contribuições para o conhecimento da fauna helmintolojica brasileira. Mem Inst Oswaldo Cruz 1915; 7(2): 146-172. http://dx.doi. org/10.1590/S0074-02761915000200002.

Vicente JJ, Rodrigues HO, Gomes DC, Pinto RM. Nematóides do Brasil. Parte IV: nematóides de aves. Rev Bras Zool 1995;12(1 Suppl 1): 1-273. http://dx.doi.org/10.1590/S0101-81751995000500001.

Vita GF, Ferreira I, Pereira MAVC, Azevedo JR, Sanavria A, Barbosa CG, et al. Eficácia de Chenopodium ambrosioides (erva-de-santa-maria) no controle de endoparasitos de Gallus gallus (galinha caipira). Pesq Vet Bras 2014; 34(1):39-45. http://dx.doi.org/10.1590/S0100-736X2014000100007.

Yadav AK, Tandon V. Helminth parasitism of domestic fowl (Gallus domesticus L.) in a sub-tropical high-rainfall area of India. Beitr Trop Landwirtsch Veterinarmed 1991; 29(1): 97-104. PMid:1930108. 